of aortic arch rupture, we could not remove the covered portion of the endoprosthesis by pulling it. We had to cut and remove each branch separately, which extended the duration of circulatory arrest significantly. The proximal suture of the arch reconstruction was difficult to perform because of fibrosis of the tissues.

In our case femoral vein cannulation was impossible; the cannula stopped in the iliac vein with the patient in the left thoracotomy position as well as the dorsal decubitus position. A good venous return is needed for circulatory arrest, so we cannulated the pulmonary artery trunk This kind of cannulation entails considerable risk because of the fragility of the tissue, and the pulmonary artery may be torn when cannulated. Moreover, occluding the cannula to avoid leakage of blood is difficult.

We found a large communication between the two channels facing the proximal uncovered part of the stent. We do not know whether this communication existed before or was caused by the insertion of the stent, but it was the cause of failed endovascular treatment in our case. We did not use a balloon to expand the stent when deploying the endoprosthesis to avoid any risk of creating a communication between the two channels.

These findings suggest the difficulties associated with the endovascular repair of the dissections. In chronic dissection, multiple reentry points between the two lumina may be found on the descending thoracic aorta, making endovascular treatment hazardous. If secondary surgery is required, the repair is more difficult than it is in primary surgery because aortic crossclamping is impossible. Therefore the explantation of the endoprosthesis and the reconstruction of the aortic arch must be done under circulatory arrest. The explantation of the stent graft is also technically difficult, because it is deeply embedded in the aortic wall.

We thank Nancy Richardson-Peuteuil for her editorial assistance.

\section{References}

1. Ueda Y, Miki S, Okita Y, Tahata T, Ogino H, Sakai T, et al. Protective effect of continuous retrograde cerebral perfusion on the brain during deep hypothermic systemic circulatory arrest. J Card Surg. 1994;9:58495.

2. Coselli JS, Conklin LD, LeMaire SA. Thoracoabdominal aortic aneurysm repair: review and update of current strategies. Ann Thorac Surg. 2002;74:S1881-4.

\title{
Should heart transplantation be considered as a treatment option for patients aged 70 years and older?
}

\author{
Jeffrey A. Morgan, MD, Ranjit John, MD, Donna M. Mancini, MD, and Niloo M. Edwards, MD, New York, NY
}

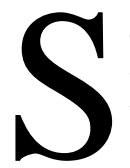

everal studies have demonstrated favorable results after orthotopic cardiac transplantation in recipients of advanced age. ${ }^{1-4}$ These studies have demonstrated similar survival in elderly patients as compared to that of younger patients undergoing heart transplantation. This has resulted in a relaxation of the upper age limit for cardiac transplantation in many centers. However, some transplant centers continue to view advanced recipient age as a contraindication to transplantation because of concerns regarding decreased survival in this cohort. ${ }^{5-7}$ This study was conducted to analyze and compare our experiences with older (70 years and older) versus younger

From the Department of Surgery, Division of Cardiothoracic Surgery, College of Physicians and Surgeons, Columbia University, New York, NY.

Received for publication Nov 27, 2003; accepted for publication Dec 16, 2003.

Address for reprints: Jeffrey A. Morgan, MD, Columbia University, College of Physicians and Surgeons, 177 Fort Washington Ave, Milstein Hospital 7GN-435, New York, NY 10032 (E-mail: jm2240@columbia. edu).

J Thorac Cardiovasc Surg 2004;127:1817-9

$0022-5223 / \$ 30.00$

Copyright $\odot 2004$ by The American Association for Thoracic Surgery

doi:10.1016/j.jtcvs.2003.12.035 (younger than 70 years) recipients with respect to perioperative and long-term survivals.

\section{Patients and Methods}

Between January 1992 and February 2003, a total of 939 orthotopic cardiac transplants were performed at the New York Presbyterian Hospital-Columbia Medical Center, New York. Of these, $10(1.1 \%)$ were performed in patients 70 years old or older (range 70.2-74.8 years). These patients were compared with patients younger than 70 years (range 18.3-69.8 years) at the time of transplantation. Pediatric patients (younger than 18 years; $n=$ 115) were excluded. Outcome measures included perioperative and long-term posttransplantation survivals.

Statistical analysis. Data were represented as frequency distributions and percentages. Values of continuous variables were expressed as mean $\pm \mathrm{SD}$. Continuous variables were compared with paired $t$ tests, whereas categorical variables were compared by means of $\chi^{2}$ tests. Kaplan-Meier analysis was used to calculate survival along with a log-rank $P$ value when comparing groups. Actuarial survivals at $1,3,5$, and 10 years after transplantation were calculated by constructing life tables. Significant predictors of mortality were identified with multivariate Cox proportional hazard models. All data were analyzed with the SPSS 11.5 software package (SPSS Inc, Chicago, Ill). 
TABLE 1. Baseline clinical characteristics of patients

\begin{tabular}{|c|c|c|c|}
\hline Variable & $\geq 70 \mathrm{y}$ & $<70$ y & $\begin{array}{c}P \\
\text { value* }^{*}\end{array}$ \\
\hline \multicolumn{4}{|l|}{ Recipient characteristics } \\
\hline Age $(y$, mean $\pm S D)$ & $72.2 \pm 1.6$ & $51.6 \pm 12.6$ & $<.001$ \\
\hline \multicolumn{4}{|l|}{ Sex (No.) } \\
\hline Male & $9(90.0 \%)$ & $629(77.3 \%)$ & .339 \\
\hline Female & $1(10.0 \%)$ & $185(22.7 \%)$ & \\
\hline \multicolumn{4}{|l|}{ Race (No.) } \\
\hline White & $9(90.0 \%)$ & $617(75.8 \%)$ & .296 \\
\hline Black & $0(0.0 \%)$ & $103(12.7 \%)$ & .229 \\
\hline Other & $1(10.0 \%)$ & $94(11.5 \%)$ & .879 \\
\hline Height (cm, mean \pm SD) & $179.8 \pm 6.0$ & $172.1 \pm 11.1$ & .068 \\
\hline Weight $(\mathrm{kg}$, mean $\pm \mathrm{SD})$ & $75.4 \pm 18.7$ & $74.0 \pm 15.9$ & .812 \\
\hline $\begin{array}{l}\text { Left ventricular assist } \\
\text { device (No.) }\end{array}$ & $0(0.0 \%)$ & $175(21.5 \%)$ & .099 \\
\hline $\begin{array}{l}\text { Male-female mismatch } \\
\text { (No.) }\end{array}$ & $5(50.0 \%)$ & $464(57.0 \%)$ & .657 \\
\hline Retransplantation (No.) & $0(0.0 \%)$ & $45(5.5 \%)$ & .444 \\
\hline \multicolumn{4}{|l|}{ Donor characteristics } \\
\hline $\begin{array}{c}\text { Donor ischemic time } \\
(\min , \text { mean } \pm S D)\end{array}$ & $195.0 \pm 50.9$ & $175.7 \pm 61.4$ & .157 \\
\hline Age $(y$, mean $\pm S D)$ & $41.6 \pm 16.3$ & $32.2 \pm 13.1$ & .061 \\
\hline
\end{tabular}

${ }^{*} P$ value from independent samples $t$ tests.

\section{Results}

Recipient data. Table 1 outlines the baseline clinical demographic data of patients in both groups. Mean ages were 72.2 \pm 1.6 years (70.2-74.8 years) in the older group and 51.6 \pm 12.6 years (18.3-69.8 years) in the younger group $(P<.001)$. Sex and ethnicity distributions were similar in both groups $(P=.339, P=$ $.296, P=.229, P=.879)$. Left ventricular assist devices were present in a greater percentage of patients younger than 70 years $(21.5 \%$ vs $0.0 \%)$, although the difference was not statistically significant $(P=.099)$. There were no retransplantations in patients 70 years or older, versus $45(5.5 \%)$ in patients younger than 70 years.

Donor data. There was no statistically significant difference in donor ischemic time between the groups, although donor ischemic time was higher in the older group $(195.0 \pm 50.9$ minutes for 70 years and older vs $175.7 \pm 61.4$ minutes for younger than 70 years, $P=.157)$. There was a trend toward significance for increased donor age in the older group $(41.6 \pm 16.3$ years for 70 years and older vs $32.2 \pm 13.1$ years for younger than 70 years, $P=.061$ ).

Survival. Overall survivals are depicted in Figure 1. There was no statistically significant difference in long-term survival between the groups $(P=.790)$. Actuarial survivals at $1,3,5$, and 10 years were $89.5 \%, 89.5 \%, 89.5 \%$, and $44.7 \%$, respectively, for the older group, and $83.6 \%, 77.9 \%, 72.0 \%$, and $51.8 \%$, respectively, for the younger group.

Cox proportional hazard models. Advanced recipient age was not an independent predictor of adverse outcome in multivariate analysis (odds ratio $0.464,95 \%$ confidence interval $0.246-0.688, P$ $=.851$, standard error 0.278 ).

\section{Discussion}

With increases in life expectancy and thus in the elderly population, more elderly patients are being seen by cardiologists and

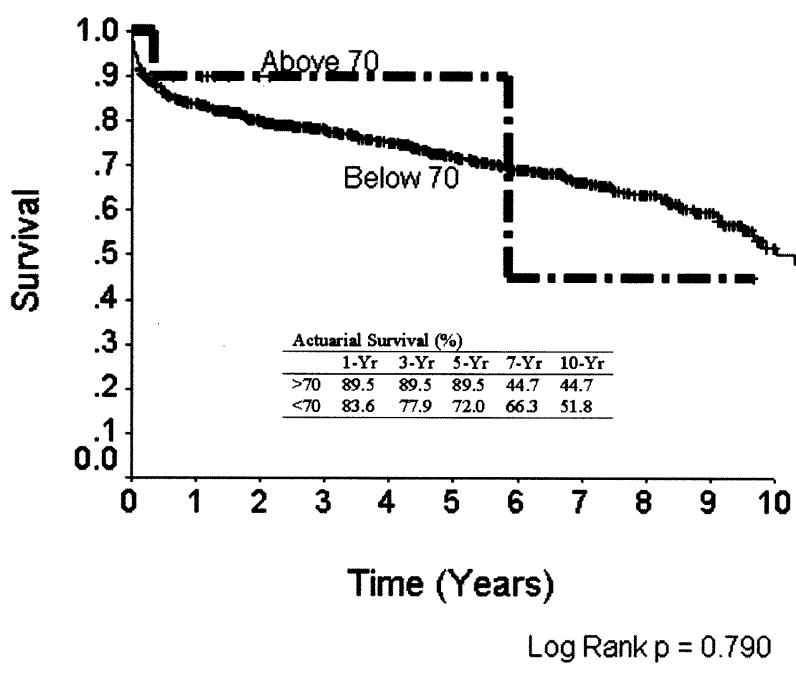

Figure 1. Long-term survival after cardiac transplantation for recipients $\mathbf{7 0}$ years old or older versus those younger than $\mathbf{7 0}$ years during past 11 years at Columbia Presbyterian Medical Center. There was no statistically significant difference in overall survival between groups $(P=.790)$.

cardiac surgeons for end-stage heart failure. ${ }^{8}$ There is an increased need for cardiac surgical procedures in the elderly population. ${ }^{8}$ Although transplantation is an effective treatment for end-stage heart failure, many transplant centers are reluctant to perform transplantation in elderly patients, even though there are data that indicate that this subgroup of patients can undergo transplantation with a survival similar to that of younger recipients. ${ }^{9-11}$

In our series of patients 70 years old or older at the time of transplantation, there was no significant difference in short or long-term survival with respect to patients younger than 70 years. Recipient age was not a risk factor for mortality and should not serve as a contraindication for transplantation. Limitations of this study include those related to a retrospectively performed analysis. Identification of clinical variables was obtained by chart review, which has inherent limitations, such as access and incompleteness of the data. Notwithstanding these limitations, our results argue that elderly patients should not be denied transplantation solely on the basis of advanced age. These patients deserve a careful medical evaluation to determine whether they are appropriate transplant candidates. When the procedure is performed in carefully selected elderly patients, it is associated with an outcome similar to that in younger patients.

\section{References}

1. Heroux AL, Costanzo-Nordin MR, O'Sullivan JE, Kao WG, Liao Y, Mullen GM, et al. Heart transplantation as a treatment option for end-stage heart disease in patients older than 65 years of age. $J$ Heart Lung Transplant. 1993;12:573-9.

2. Blanche C, Matloff JM, Denton TA, Czer LS, Fishbein MC, Takkenberg JJ, et al. Heart transplantation in patients seventy years of age and older: initial experience. Ann Thorac Surg. 1996;62:1731-6.

3. Blanche C, Takkenberg JJ, Nessim S, Cohen M, Czer LS, Matloff JM, 
et al. Heart transplantation in patients 65 years of age and older: a comparative analysis of 40 patients. Ann Thorac Surg. 1996;62: 1442-7.

4. Blanche C, Blanche DA, Kearney B, Sandhu M, Czer LS, Kamlot A, et al. Heart transplantation in patients seventy years of age and older: a comparative analysis of outcome. J Thorac Cardiovasc Surg. 2001; 121:532-41.

5. Bull DA, Karwande SV, Hawkins JA, Neumayer LA, Taylor DO, Jones $\mathrm{KW}$, et al. Long-term results of cardiac transplantation in patients over sixty years. J Thorac Cardiovasc Surg. 1996;111:423-8.

6. Borkon AM, Muehlebach GF, Jones PG, Bresnahan DR Jr, Genton $\mathrm{RE}$, Gorton ME, et al. Analysis of the effect of age on survival after heart transplantation. J Heart Lung Transplant. 1999;18:668-74.

7. Hosenpud JD, Bennett LE, Keck BM, Fiol B, Boucek MM, Novick RJ. The registry of the International Society for Heart and Lung Trans- plantation. Sixteenth official report-1999. J Heart Lung Transplant. 1999; 18:611-26

8. Tsai TP, Chaux A, Matloff JM, Kass RM, Gray RJ, DeRobertis MA, et al. Ten-year experience of cardiac surgery in patients aged 80 years and over. Ann Thorac Surg. 1994;58:445-51.

9. John R, Rajasinghe HA, Chen JM, Weinberg AD, Sinha P, Mancini $\mathrm{DM}$, et al. Long-term outcomes after cardiac transplantation: an experience based on different eras of immunosuppressive therapy. Ann Thorac Surg. 2001;72:440-9.

10. Marelli D, Laks H, Kobashigawa JA, Bresson J, Ardehali A, Esmailian F, et al. Seventeen-year experience with 1,083 heart transplants at a single institution. Ann Thorac Surg. 2002;74:1558-67.

11. Robbins RC, Barlow CW, Oyer PE, Hunt SA, Miller JL, Reitz BA, et al. Thirty years of cardiac transplantation at Stanford University. J Thorac Cardiovasc Surg. 1999;117:939-51.

\title{
Superior vena cava stenosis: A delayed BioGlue complication
}

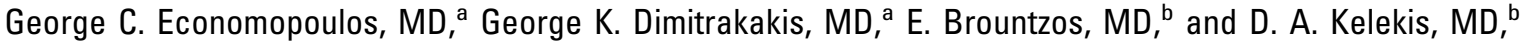 \\ North Faliro and Athens, Greece
}

W e report a case of superior vena cava (SVC) stenosis with upper body venous hypertension after application of biologic glue in the vicinity of the SVC after a double valve replacement and an annuloplasty procedure. The SVC stenosis was managed successfully with balloon dilatation and stent placement.

\section{Clinical Summary}

A 63-year-old man was scheduled for double (aortic and mitral) valve replacement and tricuspid valve annuloplasty. Bicaval cannulation was performed through the right atrial appendage for the SVC and the atriocaval junction for the inferior vena cava; standard ascending aortic cannulation was also performed. Antegrade and retrograde cold blood cardioplegia with moderate core hypothermia $\left(30^{\circ} \mathrm{C}\right)$ constituted the cardioprotective strategy. The exposure of mitral and tricuspid valves was obtained through a superior transseptal approach; exposure of the aortic valve was obtained through a transverse aortotomy. After the mitral and the aortic valve replacements, a DeVega tricuspid valve annuloplasty, and closure of the atriotomy incision, there was persistent bleeding from the dome of the left atrium. Despite adequate suturing, local

From the Department of Cardiac Surgery, Metropolitan Hospital, North Faliro, Greece, ${ }^{\mathrm{a}}$ and the Department of Radiology, University of Athens Medical School, Athens, Greece. ${ }^{\mathrm{b}}$

Received for publication Nov 29, 2003; accepted for publication Dec 16, 2003.

Address for reprints: George C. Economopoulos, MD, Director, Cardiac Surgery, Metropolitan Hospital, 9 E Makariou and 1 E Venizelou Sts, Neo Faliro 18547, Greece (E-mail: geconomo@ otenet.gr).

J Thorac Cardiovasc Surg 2004;127:1819-21

$0022-5223 / \$ 30.00$

Copyright $\odot 2004$ by The American Association for Thoracic Surgery

doi:10.1016/j.jtcvs.2003.12.041 sponge packing, reversal of all anticoagulants, and plasma and platelet transfusions, the oozing persisted. A fair amount of BioGlue (Cryolife, Inc, Kennesaw, Ga) was placed on the area, with a successful result. The patient had an uneventful recovery, and he was discharged on the ninth postoperative day.

The patient returned 8 months later, reporting headaches, dizziness especially on bending, and significant swelling of the face and neck. Echocardiography revealed a competent tricuspid valve repair and two well-functioning artificial valves, with satisfactory myocardial performance. A retroaortic and paracaval echodense mass was noted to be compressing the SVC at its junction with the right atrium (Figure 1). An upper-body venogram revealed a severe stenosis $(>90 \%)$ of the SVC (Figure 2, A). Dilatation of the SVC with 7-mm and 12-mm balloons, followed by placement of a $12 \times 64-\mathrm{mm}$ Wallstent (Boston Scientific, Watertown, Mass), successfully relieved the stenosis (Figure 2, B). The patient is doing well without recurrent stenosis 16 months after the procedure.

\section{Discussion}

After the adverse effects of cyanoacrylate-based glue on the aortic tissues became apparent, ${ }^{1-3}$ a new bovine albumin-based glue cross-linked with glutaraldehyde, BioGlue, was introduced into the cardiac surgical market as the new, nontoxic glue for hemostasis. The product is a preparation of bovine albumin cross-linked with glutaraldehyde to form a strong adhesive bond. It is supplied in a two-barrel applicator; the two compartments contain albumin and glutaraldehyde, which are mixed at the time of application. After mixture, the glue solidifies in about 30 seconds and achieves maximum strength in about 2 to 3 minutes. ${ }^{4}$ The use of BioGlue in aortic surgery was met with great initial enthusiasm, because not only did it increase the strength of the friable aortic walls in aortic dissection when it was applied between the dissected aortic layers, it was proved effective as a sealing agent at the anastomotic suture line. ${ }^{5-8}$ 